\title{
IMPACT OF PLANT GROWTH PROMOTING RHIZOBACTERIA AS BIO-CONTROL AGENTS ON CITRUS NEMATODE, TYLENCHULUS SEMIPENETRANS INFECTING BALADY ORANGE (CITRUS SINENSIS L.) AND IMPROVING ITS PRODUCTIVITY
}

\author{
Orf, O.M. Heba ${ }^{1}$; Soad, Y.S. El-Sayed ${ }^{1}$ and Sahar, H. Abdel-Baset ${ }^{2}$ \\ ${ }^{1}$ Department of Agric. Microbiol., Soils, Water and Environment Res. Inst., ARC, Giza, Egypt. \\ ${ }^{2}$ Department of Nematology, Plants Pathology Res. Inst., ARC, Giza, Egypt.
}

*Corresponding author: hebaorf1978@gmail.com Received: 10 Nov. 2019 ; Accepted: 22 Dec. 2019

\begin{abstract}
Three bacterial species of plant growth promoting rhizobacteria (PGPR) namely Paenibacillus polymyxa, Methylobacterium mesophilicum and Methylobacterium radiotolerans were tested alone or combined with humic acid as bio-control agents against the citrus nematode Tylenchulus semipenetrans under laboratory and field conditions. Results cleared that; all tested PGPR species produced IAA, HCN, ammonia, chitinase and protease enzymes and also solubilized phosphate in laboratory. P. polymyxa emphasized the superiority among other species in all PGPR properties except for phosphate solubilization, whereas $M$. radiotolerans showed highest amount of phosphorus solubilized in culture media. On the other hand, the results of the nematode survey conducted on orange, Citrus sinensis L. cv Balady grown in different localities of Ismailia and Sharkia Governorates during season 2019, revealed the presence of seven genera and species of plant-parasitic nematodes. Among which, T. semipenetrans occurred in all examined samples (100\% frequency of occurrence) with a relatively high population density of 2330 and 2640 infected juveniles $\left(\mathrm{J}_{2}\right) / 250 \mathrm{~g}$ soil in Ismailia and Sharkia Governorates, respectively. Field experiments were conducted in two different locations, at Ismailia and Sharkia Governorates to assess the effectiveness of PGPR strains alone or combined to reduce the numbers of $T$. semipenetrans during season 2019. It was found that, all treatments caused significant $(\mathrm{P} \leq 0.05)$ reduction in $T$. semipenetrans population, compared to control treatment. The nematicide, Nemathorin ${ }^{\circledR} 10 \%$ G followed by $P$.

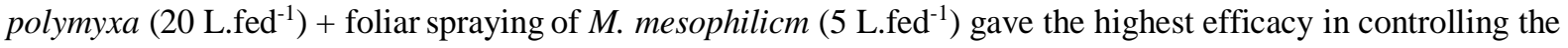
citrus nematode. Percentage reduction in numbers of $\mathrm{J}_{2} / 250 \mathrm{~g}$ soil and adult females $/ \mathrm{g}$ roots for these treatments in Ismailia Governorate were $91 \%(85.7 \%)$ and $91.4 \%(89.5 \%)$, respectively. While the parallel values in Sharkia Governorate were $90 \%(87 \%)$ and $94 \%$ (90\%), respectively. The combination of P. polymyxa and humic acid $\left(20{\left.\mathrm{~L} . f e d^{-1}\right)}\right.$ with foliar spraying of M. mesophilicm (5 L.fed ${ }^{-1}$ ) gained the third position. All treatments increased the fruit yield compared to control treatment. The highest percentages of increase were determined with Nemathorin $(160 \%$ and $206 \%)$ followed by $P$. polymyxa + Humic acid $\left(20\right.$ L.fed $\left.^{-1}\right)+$ foliar spraying of $M$. mesophilicum (155.7\% and 193\%) and M. radiotolerans $+P$. polymyxa + foliar spraying of $M$. mesophilicum (153\% and182\%) in Ismailia, and Sharkia Governorates respectively.
\end{abstract}

Key words: Citrus nematodes, Tylenchulus semipenetrans, Plant-Growth Promoting Rhizobacteria (PGPR), Paenibacillus polymyxa, Methylobacterium mesophilicum, Methylobacterium radiotolerans, humic acid, biocontrol agents.

\section{INTRODUCTION}

Citrus is one of the most important economic cro ps in many mediterranean, and subtropical countries. It is infected by many species of plant-parasitic nematodes that cause damage to the trees i.e., Tylenchulus semipenetrans, Helicotylenchus spp.,
Hoplolaimus spp., and Tylenchorhynchus spp. Among which the citrus nematode, T. Semipenetrans has spread throughout the world's citrus-growing regions and causes significant reduction in fruit yield and weight. Yield losses due to $T$. semipenetrans was found to be in the range of $10 \%$ to $30 \%$, depending on the level of infestation (Duncan, 2005). 
There are different management strategies of plant-parasitic nematodes via resistant cultivars, chemical control, biological control, and other cultural practices (Abd-Elgawad, 2013). However, the nematicides have been applied widely to control plant-parasitic nematodes with fast-acting and considerable results but, they are unfriendly methods, costly and produce environmental hazards. For instances, aldicarb residues exceeded the reference doses in orange fruits at Sharkia governorate, Egypt (Tchounwou et al., 2002). Moreover, growing public concerns about the overuse of synthetic chemical pesticides, have prompted scientists, to concentrate a large number of their studies on the biological control agents as a safe alternative to these chemical substances. For example, the assessment of soil amended with biological control agents and/or compost for control the citrus nematode, $T$. semipenetrans on sour orange (El-Mohamedy et al., 2016) and on Volkamer lime (Hammam et al. 2016).

Application of certain soil bacteria as seed or root inoculants to improve plant growth and productivity are known as plant-growth promoting rhizobacteria PGPR (Khan et al., 2012). Well known PGPRs include Bacillus, Azospirillium, Azotobacter, Burkholderia, Pseudomonas, Rhizobium, Serratia and several novel PGPRs like Methylobacterium, Azoarcus, Exiguobacterium, Paenibacillus and Pantoea etc., (Hemlata et al., 2015). According to their mode of action they can be classified as biofertilizers and biopesticides (Martinez et al., 2010). Thus, PGPR have grabbed the scientists' attention to be used as an alternative eco-friendly biological control agents. PGPR operate through either direct or indirect mechanisms or a combination of both. Direct mechanisms of plant growth promotion include the secretion of plant growth promoting metabolites like indole acetic acid (IAA), cytokinins, gibberellins, etc. and facilitating the uptake of essential nutrients (N, P, Fe, Zn, etc.) from the atmospheric air and soil. Indirect promotion of the plant growth occurs when PGPR lessen or prevent the deleterious effect of phytopathogenic organisms by the production of antibiotics, siderophores, hydrogen cyanide ( $\mathrm{HCN})$, etc. (Ashraf et al., 2013). It is also been proven that some strains of these bacteria have main role in reduction of the crop damage caused by nematodes (Zeinat et al., 2010 and Anwar-uI-Haq et al., 2011).

Paenibacillus polymyxa is an agriculturally important microbe widely studied for its plant growth-promoting and biocontrol abilities , as fixing atmospheric nitrogen, solubilizing phosphate, and producing phytohormones (Padda et al., 2017).Also, the secondary metabolites of certain Bacillus spp. are responsible for their nematocidal activity (Zhang, et al., 2016), such as production of ammonia and hydrogen cyanide HCN (Jha et al., 2015).
Methylobacterium spp are known as Pink Pigmented Facultatively Methylotrophic (PPFM) species have benefit effects on plants by several ways, where they have been found in the phyllosphere region and acts synergistically, utilizing methanol from leaves as the sole source of carbon and energy and improves plant growth by production of phytohormones auxins and cytokinins and also produce siderophore which enhanced the plant growth and acted as biocontrol agent (Omer $\boldsymbol{e t}$ al. 2004 and Madhaiyan et al.2005).

The role of PPFM-produced cytokinin in the stimulation and translocation of minerals and organic compounds in leaves, as well as the potential of plant leaves and roots to utilize siderophores produced by Methylobacterium mesophilicum have also been discussed (Ivanova $\boldsymbol{e t}$ al., 2000 and Orf $\boldsymbol{e t}$ al., 2005). Methylobacteria are also considered as plant-growth promotion bacteria by several mechanisms include phytohormones production (IAA), nitrogen metabolism and $\mathrm{N}_{2}$-fixing. Moreover, they play important role as bio-agents by suppressing plant pathogens in the rhizospher via several mechanisms such as ISR, lytic enzymes production, siderophores production and phosphate solubilization activity (Ardanov et al., 2012).

Humic acid which is known for major organic constituents of humus, has an effect on alleviating damages of plant roots infected with root-knot namatodes (Kesba and Hossam, 2012). According to research done by Kim (2016), application of humic acid treatments on infected plant roots with root-knot nematodes can reduce the contents of lipid peroxdaise and $\mathrm{H}_{2} \mathrm{O}_{2}$ in plant roots by improving the activities of antioxidants enzymes. Thus, humic acid is considered as good resource to strengthen plant roots and inhibit nematode activities at the same time.

The objective of this study is to determine the effect of citrus root inoculation with three species of PGPR as biocontrol agent alone or combined with humic acid on the citrus nematode $T$. semipenetrans performance and reproduction under field conditions.

\section{MATERIALS AND METHODS}

Plant growth promoting rhizobacteria (PGPR): Two bacterial species of PPFMs namely Methylobacterium mesophilicum and Methylobacterium radiotolerans and Paenibacillus polymyxa were used as bioagents, were kindly provided from Department of Microbiology, Soils, Water and Environment Research Institute (SWERI), Agricultural Research Center (ARC), Giza, Egypt.

Culture media: Nutrient agar medium was used for cultivation and maintenance of Paenibacillus polymyxa (Dowson, 1957), whereas, Methanol Mineral Salts (MMS) agar medium was used for 
cultivation and maintenance of Methylobacterium species. (Holland and Polacco, 1992).

Organic inoculum: Humic acid was extracted from compost, provided from Department of Microbiology, Soils, Water and Environment Research Institute (SWERI), Agricultural Research Center (ARC), Giza, Egypt, using alkali/acid fractionation procedure as proceeded by Valdrighi $\boldsymbol{e t}$ al. (1996). Some physical, chemical and biological properties of the used compost was presented in (Table 1).

Table 1. Some physical, chemical and biological properties of the used compost

\begin{tabular}{ll}
\hline Property & Value \\
\hline Bulk density $\left(\mathrm{kg} / \mathrm{m}^{3}\right)$ & 4777.2 \\
$\mathrm{pH}(1: 10)$ & 7.53 \\
E.C $\left(\mathrm{dS} / \mathrm{m}\right.$ at $\left.25^{\circ} \mathrm{C}\right)$ & 4.26 \\
Organic matter \% & 42.68 \\
Total nitrogen \% & 1.18 \\
C/N Ratio & 20.97 \\
Total phosphorus \% & 0.49 \\
Total potassium \% & 1.37 \\
Dehydrogenases $(\mu \mathrm{g}$ TPF/g dry weight/day) & 296.53 \\
Seed germination test of cress seeds $(\%)$ & 93 \\
\hline
\end{tabular}

The compost was soaked in $0.1 \mathrm{~N} \mathrm{KOH}$ extractant at ratio $1: 10 \mathrm{w} / \mathrm{v}$ for overnight at room temperature. The insoluble humin fraction was separated by filtration to obtain the filtrate of fulvic and humic acid. The filtrate was then acidified to be $\mathrm{pH} 2.0$ using $6.0 \mathrm{~N}$ $\mathrm{H}_{2} \mathrm{SO}_{4}$ and maintained at room temperature for overnight in order to precipitate humic acid. Finally, humic resuspended and neutralized to pH 6.5 using $0.1 \mathrm{~N} \mathrm{KOH.}$

\section{Assayment of PGPR activities in vitro}

Indole acetic acid production: Qualitative analysis of indole-3-acetic acid (IAA) was performed by the method of described by Brick et al. (1991). The tested rhizobacteria were grown on Luria-Bertani agar medium amended with L-tryptophan (Bakker and Schippers, 1987).

Hydrogen cyanide production: Luria-Bertani agar medium supplemented with glycine was used to detect the production of $\mathrm{HCN}$ by the rhizobacteria under investigation (Bakker and Schippers, 1987).

Ammonia formation: Fresh bacterial cultures were tested for the ammonia production by using Nessler's reagent due to Bakker and Schippers (1987).
Quantitative estimation of phosphate solubilization: Quantitative measurement of phosphorus released by tested rhizobacteria was done by growing the bacteria in Pikovskaya broth medium (Pikovskaya, 1948), the available phosphorus in medium was measured according to Watanabe and Oslen (1965).

Production of chitinase and protease enzymes: Chitinolytic and proteolytic activities of the tested rhizobacteria were indicated by the ability of those bacteria to form clear zone on agar media. Proteolytic agar medium containing $1 \%$ glucose and 1\% skimmed milk (Dunne et al., 1997), was used for protease production, while chitinolytic agar medium used for chitinase production was done according to Strzelezyk et al. (1990).

Soil used: The field experiments were conducted in two different locations, at the experimental farm of El-Kassasin Horticultural Research Station, Ismailia Governorate. ARC, Egypt, and in Arab Company for Agricultural Projects, Wadi El-Molak, Sharkia Governorate, Egypt in season 2019.

The physical, chemical and biological properties of the two samples of soils used were conducted according to Jackson (1973) and are shown in Table (2).

Survey study: The present survey was carried out in selected randomly orchards of 10 to 15 years old orange, Citrus sinensis L. cv Balady grown in different localities of Ismailia and Sharkia Governorates during the season 2019. Samples were taken from these orchards at different times (February, March, and April). The soil samples were collected to a depth of $20-30 \mathrm{~cm}$ from the rhizosphere around the feeder roots of the trees. Each sample was made of 5 sub samples which were mixed together to form a composite sample of about $0.5 \mathrm{~kg}$. The collected samples were sent in labeled polyethylene bags to the laboratory and kept in refrigerator at $5{ }^{\circ} \mathrm{C}$ until nematode extraction.

Nematode extraction, counting and identification: Each soil sample was carefully mixed and an aliquot sample of $250 \mathrm{~g}$ was processed for nematode extraction using sieving and Baermann plates technique according to the method described by Ayoub (1980), and counted under a stereomicroscope. Nematodes were identified to the generic level based on the morphology of adult females and juvenile forms according to Mai and Lyon (1975). For each genus, population density (P.D.) per $250 \mathrm{~g}$ soil and frequency of occurrence $\%$ (F.O. \%) were calculated according to Norton (1978). 
Table 2. The physical, chemical and biological properties of the used soils

\begin{tabular}{|c|c|c|c|}
\hline \multicolumn{2}{|c|}{ El-Kassasin, Ismailia Governorate } & \multicolumn{2}{|c|}{ Wadi El-Molak, Al Sharkia Governorate } \\
\hline Soil characters & Value & Soil characters & Value \\
\hline Particle size distribution \%: & & Particle size distribution \%: & \\
\hline Sand & 90.51 & Sand & 90.21 \\
\hline Silt & 2.24 & Silt & 2.14 \\
\hline Clay & 7.25 & Clay & 7.15 \\
\hline Texture grade & Sandy & Texture grade & Sandy \\
\hline Chemical characters: & & Chemical characters: & \\
\hline $\mathrm{pH}$ & 7.21 & $\mathrm{pH}$ & 7.20 \\
\hline E.C $\left(\mathrm{ds} \mathrm{m}^{-1} 25^{\circ} \mathrm{C}\right)$ & 0.18 & E.C $\left(\mathrm{ds} \mathrm{m}^{-1} 25^{\circ} \mathrm{C}\right)$ & 0.18 \\
\hline Soluble cations (meq/L): & & Soluble cations (meq/L): & \\
\hline $\mathrm{Ca}^{++}$ & 0.52 & $\mathrm{Ca}^{++}$ & 0.53 \\
\hline $\mathrm{Mg}^{++}$ & 0.26 & $\mathrm{Mg}^{++}$ & 0.27 \\
\hline $\mathrm{Na}^{+}$ & 0.19 & $\mathrm{Na}^{+}$ & 0.19 \\
\hline $\mathrm{K}^{+}$ & 0.07 & $\mathrm{~K}^{+}$ & 0.09 \\
\hline Soluble anions (meq/L): & & Soluble anions (meq/L): & \\
\hline $\mathrm{CO}_{3}^{--}$ & -- & $\mathrm{CO}_{3}^{--}$ & -- \\
\hline $\mathrm{HCO}_{3}^{-}$ & 0.12 & $\mathrm{HCO}_{3}^{-}$ & 0.13 \\
\hline $\mathrm{CL}^{-}$ & 0.26 & $\mathrm{CL}^{-}$ & 0.25 \\
\hline $\mathrm{SO}_{4}^{--}$ & 0.64 & $\mathrm{SO}_{4}^{--}$ & 0.66 \\
\hline *Dehydrogenase enzyme & 344.19 & *Dehydrogenase enzyme & 334.22 \\
\hline
\end{tabular}

*DHG enzyme activity was expressed as $\mu \mathrm{g}$ TPF/100g dry soil/24h.

\section{Field experiment}

Evaluation of PGPR as plant growth promoting and biocontrol agents in vivo

Two field experiments were conducted in the experimental farm of El-Kassasin Horticultural Research Station, Ismailia Governorate, and in Arab Company for Agricultural Projects, Wadi El-Molak, Sharkia Governorate during the period from February to November 2019 to determine the effectiveness of biocontrol agents namely $P$. polymyxa, $M$. radiotolerans and M.mesophilicum against $T$. semipenetrans in Balady orange orchards. The trees were grafted on sour orange rootstock (Citrus aurantium), nearly uniform in vigor, size, age (14 years), and spaced at $3 \times 7 \mathrm{~m}$ apart (175 trees / Fed.). The surface drip irrigation system was used in the two orchards.

\section{The applied treatments were used as follows:}

1- Inoculation with $M$. radiotolerans alone at rate of 10L.Fed ${ }^{-1}\left(\mathrm{~T}_{1}\right)$.

2- Inoculation with $P$. polymyxa alone at rate of 10L.Fed ${ }^{-1}\left(\mathrm{~T}_{2}\right)$.

3- Addition of Humic acid alone at rate of 10L.Fed ${ }^{1}\left(\mathrm{~T}_{3}\right)$.

4- Inoculation with $M$. radiotolerans $+P$. polymyxa $(1: 1 \mathrm{vol} / \mathrm{vol})$ at rate of $10 \mathrm{~L} . \mathrm{Fed}^{-1}\left(\mathrm{~T}_{4}\right)$.

5- Inoculation with $M$. radiotolerans + Humic acid $(1: 1 \mathrm{vol} / \mathrm{vol})$ at rate of $10 \mathrm{~L} . \mathrm{Fed}^{-1}\left(\mathrm{~T}_{5}\right)$.

6- Inoculation with $P$. polymyxa + Humic acid (1:1 $\mathrm{vol} / \mathrm{vol})$ at rate of $10 \mathrm{~L}$ Fed $^{-1}\left(\mathrm{~T}_{6}\right)$.
7- Inoculation with $M$. radiotolerans $+P$. polymyxa + Humic acid $(1: 1: 1 \mathrm{vol} / \mathrm{vol})$ at rate of 10L.Fed ${ }^{1}\left(\mathrm{~T}_{7}\right)$.

8- Inoculation with $M$. radiotolerans alone at rate of 20L.Fed ${ }^{-1}\left(T_{8}\right)$.

9- Inoculation with $P$. polymyxa alone at rate of 20L.Fed ${ }^{-1}\left(\mathrm{~T}_{9}\right)$.

10- Addition of Humic acid alone at rate of 20L.Fed ${ }^{-1}\left(\mathrm{~T}_{10}\right)$.

11- Inoculation with $M$. radiotolerans $+P$. polymyxa $(1: 1 \mathrm{vol} / \mathrm{vol})$ at rate of $20 \mathrm{~L}$.Fed ${ }^{-1}\left(\mathrm{~T}_{11}\right)$.

12- Inoculation with $M$. radiotolerans + Humic acid at rate of $20 \mathrm{~L}$. Fed $^{-1}\left(\mathrm{~T}_{12}\right)$.

13- Inoculation with $P$. polymyxa + Humic acid $M$. radiotolerans at rate of 20L.Fed ${ }^{-1}\left(\mathrm{~T}_{13}\right)$.

14- Inoculation with M.radiotolerans $+P$. polymyxa + Humic acid $(1: 1: 1 \mathrm{vol} / \mathrm{vol})$ at rate of 20L.Fed ${ }^{1}\left(\mathrm{~T}_{14}\right)$.

15-Additon of Nemathorin ${ }^{\circledR} 10 \% \mathrm{G}$ at rate of 12.5 $\mathrm{kg} \cdot \mathrm{Fed}^{-1}\left(\mathrm{~T}_{15}\right)$.

16- Control (left without any amendment or chemical) $\left(\mathrm{T}_{16}\right)$.

Foliar spraying (F) with M.mesophilicum at rate of $5 \mathrm{~L} . \mathrm{Fed}^{-1}$ was applied with all biocontrol agents treatments at flowering stage one time to induce systemic resistance and improve productivity of citrus trees. Before the application of biocontrol agents, the nematode population was assessed. Nematodes were extracted from $250 \mathrm{gm}$ soil, according to sieving and modified Baermann 
technique. Roots were stained with acid fuchsin in lactic acid (Byrd et al., 1983) and counted for females $/ \mathrm{g}$ root. The nematode population was recorded in soil and roots after biocontrol agents were applied. Reduction percentages (Red.\%) of number of female $/ 1 \mathrm{~g}$ root, and second stage juveniles $\left(\mathrm{J}_{2}\right)$ in soil were counted in comparison with a control treatment. The bioagents were applied every 15 days at four times, from $1^{\text {st }}$ March to $15^{\text {th }}$ April 2019. The treatments were added individually or combined at two rates, i.e., 10L.Fed ${ }^{-1}$ and 20L.Fed ${ }^{-1}$ for each or mixed treatment. Five trees were treated with the nematicide Nemathorin $₫ 10 \%$ $\mathrm{G}$ at the recommended rate of $12.5 \mathrm{~kg} . \mathrm{Fed}^{-1}$. Another five trees were kept as a control (without any treatment or nemiticide). During October 2019, the harvest of each tree was picked separately to obtain the exact number of oranges from each tree individually. The average weight of 10 randomly selected mature fruits has been calculated for each tree $(\mathrm{g})$. Increasing percentages $(\%)$ of fruit yield/tree were counted in comparison with a control treatment.

Statistical analysis: All experiments were performed twice in a completely randomized design with 5replicates in each treatment. Data were subjected to analysis of variance (ANOVA) using MSTAT-C program version 2.10 (Anonymous, 1991). Means were compared by Duncan's multiple range test at $\mathrm{P} \leq 0.05$ probability (Duncan,1955).

\section{RESULTS AND DISCUSSION}

\section{In vitro assessment of rhizobacteria as bioagents} and growth promoters

\section{Mechanisms of PGPR in nematode suppression}

Different mode of actions had exhibited by the rhizobacteria in the rhizosphere to suppress plant parasitic nematodes. The mechanism of nematode suppression can be divided into two categories (i) direct antagonism: such as producing enzymes (chitinase and protease enzymes) and other metabolic products such as HCN and ammonia(.ii)indirect antagonism :effect either by plant growth promotion via production of regulating hormones (IAA) and support the plant with minerals via phosphate solubilization or by inducing systemic resistance.

\section{Indole acetic acid formation:}

In vitro plant growth promoting hormones IAA produced by tested PGPR is depicted in Table (3), in which all PGPRs studied produced IAA, but they greatly fluctuated in color intensity apparent on L.B. medium amended with tryptophan. The highest color intensity was obtained with $P$. polymyxa as compared to the other two bacteria. In this respect, many investigators evidenced the ability of various PGPRs for producing indole compounds, particularly in the presence of tryptophan as essential for indole secretion (Ahmed and Hasnain 2010). In this concern, Saraf et al. (2010) stated that, Plant growth promotion by Methylobacterium include synthesis of the major plant hormones IAA. Also, Madhaiyan et al. (2006) reported that the Methylobacterium inoculation lead to increase IAA accumulation in plants that leads to induce plant growth and development. High proportion of rhizomicroorganisms including P.polymyxa are capable to produce plant growth hormone (IAA), which act as root growth stimulator and increase the root branching and surface area as well( Badawi et al., 2011 \& El-Sayed et al., 2016).

\section{HCN and ammonia secretion}

Also results in Table (3) showed the potential role in production of $\mathrm{HCN}$ and ammonia. Therefore, the ability of tested rhizobacteria to produce cyanide and ammonia was done through qualitative screening through color intensity. The visual inspection of the plates appeared that all rhizobacterial assayed has cyanogenic potential as the result of changing the color of indicator paper. However, color intensity was gradually different amongst the tested microorganisms, in which $P$. polymyxa may considered as strong $\mathrm{HCN}$ producer followed by $M$. radiotolerans while, M.mesophilicum showed lowest color intensity.

Same trend was observed in the production of ammonia by tested PGPR. P. polymyxa had greater ability in ammonia production which scored $(+++)$ followed by $M$. radiotolerans (++) and $M$. mesophilicum (+).

The antagonistic effect of tested PGPR may have occurred through their production of nematoxic chemicals such as $\mathrm{HCN}$ and $\mathrm{NH}_{3}$, which are toxic to nematodes (Abdel-Baset and El-Egami, 2019). This is in agreement with Khan et al. (2012) \& Siddiqui and Ehtshamul Haque (2001) who reported that these metabolites may affect egg hatching and nematode parasitism.

\section{Phosphate solubilization}

The ability of the tested bacteria used in the study to solubilize phosphate in the cultures is shown in Table (3). The greatest solubilization in culture broth media was induced by $M$. radiotolerans followed by $P$. polymyxa, and $M$. mesophilicum in which the amounts of phosphorus released by $M$. radiotolerans, $P$. polymyxa and $M$. mesophilicum were (82.21,77.26 and 73.50), respectively. Goldstein et al. (2003) proposed direct oxidation of glucose to gluconic acid (GA) as a major mechanism for mineral phosphate solubilization (MPS) in Gram-negative bacteria. Methylobacterium spp. is influencing the growth promotion through producing gluconic acid and solubilizing insoluble phosphates, to combat 
phytopathogens and induce systemic resistance that induce plant growth (Jha et al., 2010).

Large amounts of solubilized phosphorus in the soil may have an inhibitory effect on the nematode. (Khan et al., 2012). Phosphate -solubilizing microorganisms are the most important and may prove efficient biocontrol agents of plant nematodes. The Phosphate Solubilizing Microorganisms (PSMs) may suppress rhizospheric nematode population by promoting host growth through solubilizing the minerals in soil (Siddiqui and Shaukat, 2004), inducing systemic resistance and/or producing nematoxic metabolites (Khan et al., 2009). In this connection, Pandy et al. (2008) considered $P$. polymyxa as the promoting phosphate- solubilizer inhabiting agricultural soils and possess potential of nematode antagonism.

Table 3. In vitro evaluation of the rhizobacteria for exerting plant growth promotion and biocontrol properties.

\begin{tabular}{|c|c|c|c|c|}
\hline PGF & -property & P.polymyxa & M.mesophilicum & M.radiotolerans \\
\hline IAA & Color intensity & +++ & + & ++ \\
\hline $\mathbf{H C N}$ & Color intensity & +++ & + & ++ \\
\hline $\begin{array}{l}\text { Ammonia } \\
\text { formation }\end{array}$ & Color intensity & +++ & + & ++ \\
\hline $\begin{array}{l}\text { Phsphate } \\
\text { solubilization }\end{array}$ & Quantity(ppm) & 77.26 & 73.50 & 82.21 \\
\hline $\begin{array}{l}\text { Chitinase } \\
\text { production } \\
\text { Protease }\end{array}$ & Zone diameter $(\mathrm{cm})$ & 3.2 & 1.9 & 2.5 \\
\hline production & Zone diameter $(\mathrm{cm})$ & 3.0 & 1.5 & 1.9 \\
\hline+ Low & ++ Moderate & +++ high & & \\
\hline
\end{tabular}

\section{Detection for lytic enzymes formation}

Also, data in Table (3) exhibited the ability of tested rhizobacteria to produce lytic enzymes represented in chitinase and protease enzymes. In which all bacteria under investigation have the ability to form clear zone around the grown colonies. Results revealed that $P$. polymyxa, $M$. mesophilicum and $M$. radiotolerans exhibited a chitinolytic and proteolytic activity. The three tested microorganisms formed clear zone with different diameter 3.2, 1.9 and $2.5 \mathrm{~cm}$ for $P$. polymyxa, M. mesophilicum and $M$. radiotolerans, respectively. However, $P$. polymyxa showed higher proteolytic activity as exerted $3.0 \mathrm{~cm}$ diameter of inhibition, while $M$. mesophilicum and $M$. radiotolerans formed clear zones with diameter 1.5 and $1.9 \mathrm{~cm}$ respectively. The results are in agreement with Mena and Pimentel (2002) who reported reduction in the Tricodorid nematode population in potato due to plant treatment with B. mycoides and Pseudomonas sp. Chitinase also considered as defense enzyme that initiate the induction of resistance by producing phytoalexine and phenolic compounds (Pokhare et al., 2012, Mhatre et al., 2017 and Viswanathan et al., 2003).

Also, Meena et al. (2012) reported that the highest enzymatic activity with lowest nematode population in tomato when treated with PGPR.

Since different structural proteins are present in different life stage of nematodes, where nematode eggs are composed of chitin/ protein complex. Thus, protease enzyme considered as nematicidal activity of biocontrol agents. In which protease can hydrolyses peptide bonds and N-acetyl-Dglucosamine polysaccharide chain, such as those found in nematode eggs composition (CastanedaAlvarez \& Abaillay, 2016).

Frequency of occurrence and population density of nematode genera or species infested Balady orange orchards in Ismailia and Sharkia Governorates

The occurrence and population density of plantparasitic nematodes infested Balady orange orchards in Ismailia and Sharkia Governorates are listed in Table (4).

Data showed that, the highest occurrence was recorded with the citrus nematode, $T$. semipenetrans.Since, the percentage of occurrence of in the surveyed orchards was $100 \%$. While, the second widely distributed genus is the dagger nematode Xiphinema spp., with the occurrence of $15 \%$ and $7 \%$ in Ismailia, and Sharkia Governorates, respectively. In the meantime, the lowest distributed genus in Sharkia Governorate was the stubby root nematode, Trichodorus spp., with $2 \%$ frequency of occurrence. While, the reniform nematode, Rotylenchulus reniformis was the lowest distributed species in Ismailia Governorate, with the occurrence of $3 \%$. On the other hand, a relatively higher value of population density was detected with $T$. semipenetrans in Ismailia and Sharkia Governorates (2380 and 2649 juveniles per $250 \mathrm{~g}$ soil, respectively). 
Table 4. Population density (P.D.) and frequency of occurrence (F.O.) \% of nematode genera and species infected Balady orange in Ismailia and Sharkia Governorates during season, 2019

\begin{tabular}{lcccc}
\hline \multirow{2}{*}{ Nematode genera or species } & \multicolumn{2}{c}{ Ismailia Governorate } & \multicolumn{2}{c}{ Sharkia Governorate } \\
\cline { 2 - 5 } & P.D. & F.O. $(\%)$ & P.D. & F.O. $(\%)$ \\
\hline Helicotylenchus spp. & 60 & 12 & 40 & 5 \\
Hoplolaimus spp. & 20 & 7 & 20 & 4 \\
T. semipenetrans & 2380 & 100 & 2640 & 100 \\
Longidorus spp. & 24 & 10 & - & - \\
Trichodorus spp. & 40 & 6 & 20 & 2 \\
Xiphinema spp. & 80 & 15 & 52 & 7 \\
Rotylenchulus reniformis & 20 & 3 & - & - \\
\hline
\end{tabular}

Population Density (P.D.) = Total numbers of individuals of each genus per $250 \mathrm{~g}$ soil/ Number of samples containing this genus.

Frequency of Occurrence \% (F.O. \%) = Number of samples containing a certain genus/ total number of collecting samples X 100

The survey results confirmed by AbdElgawad (1992), Ibrahim (1994), Radwan and Fatima (2003), and Baklawa (2004) who mentioned that $T$. semipenetrans was the most common nematode associated with citrus root seedlings and had the highest distribution on collecting samples from several nurseries in Kalubiya, Sharkiya, Ismailia and Behira Governorates in Egypt. Furthermore, ElBanhawy et al. (2006) reported that citrus nematode, $T$. semipenetrans was recorded throughout, citrus fruit trees in the Nile Delta and Middle Egypt.

\section{Efficacy of bio -agents on $T$. semipenetrans infected Balady orange trees in Ismailia Governorate}

Two bio- agents (M. radiotolerans and P.polymyxa) and humic acid, alone and in combination at two different rates in the presence of foliar spraying with $M$. mesophilicum were studied against citrus nematode, $T$. semipenetrans under field conditions. Data in Table (5) reveled that all treatments caused significant $(\mathrm{P} \leq 0.05)$ reduction in $T$. semipenetrans population, compared to control treatment. Two months after the fourth application (June 2019) of treatments, the nematicide, Nemathorin ${ }^{\circledR} 10 \%$ $\mathrm{G}\left(\mathrm{T}_{15}\right)$ recorded the highest percentage of reduction in number of second stage juveniles $\left(\mathrm{J}_{2}\right) / 250 \mathrm{~g}$ soil $(85.0 \%)$, and number of adult females/1g roots $(89.6 \%)$, respectively. The populations of $T$. semipenetrans were obviously decreased with increasing bio-agents rates. The combination treatment of $P$. polymyxa+ Humic acid at the rate $20 \mathrm{~L} . F e d^{-1}$ in the presence of foliar spraying of $M$. mesophilicum $\left(\mathrm{T}_{13}\right)$ recorded the highest percentage of reduction in the number of $\mathrm{J}_{2} / 250 \mathrm{~g}$ soil $(68 \%)$.

Meanwhile, the highest percentage of reduction in the number of adult females/1g roots was $88 \%$ with the combination treatment of $M$. radiotolerans $+P$. polymyxa at the rate 20L. fed $^{-1}$ in the presence of foliar spraying with M. mesophilicum $\left(\mathrm{T}_{11}\right)$. While, the humic acid at rate of $10 \mathrm{~L} . f e d^{-1}$ in the presence of foliar spraying $\left(\mathrm{T}_{3}\right)$ was relatively the least effective treatment in percentage of reduction in the number of $J_{2} / 250 \mathrm{~g}$ soil and the number of adult females/1g roots with values $34 \%$, and $51.7 \%$ respectively.

On the other hand, five months after the fourth application (September, 2019), the nematicide, Nemathorin ${ }^{\circledR} 10 \% \quad \mathrm{G}\left(\mathrm{T}_{15}\right)$ had the highest efficacy in controlling the citrus nematode population. Since, the highest values of percentage reduction in number of $\mathrm{J}_{2} / 250 \mathrm{~g}$ soil and number of adult females $/ \mathrm{g}$ roots were $91 \%$ and $91.4 \%$ respectively, followed by the application of $P$. polymyxa at a rate of $20 \mathrm{~L}$. fed $^{-1}+$ foliar spraying of $M$. mesophilicm at rate of $5 \mathrm{~L} \mathrm{fed}^{-1}\left(\mathrm{~T}_{9}\right)$ with the parallel values of $85.7 \%$, and $89.5 \%$, respectively. The combination of $P$. polymyxa with humic acid at a rate of 20L.fed ${ }^{-1}$ with foliar spraying of $M$. mesophilicm at a rate of $5 \mathrm{~L} . \mathrm{fed}^{-1}\left(\mathrm{~T}_{13}\right)$ was the third effective treatment in reducing the population of citrus nematode in soil and root with $83 \%$, and $88 \%$ respectively. 
Table 5. Efficacy of biocontrol agents and humic acid alone and in combination, at two different rates with foliar spraying of Methylobacterium mesophilicm against citrus nematode, $T$. semipenetrans on Balady orange trees in Ismailia Governorate under field conditions

\begin{tabular}{|c|c|c|c|c|c|c|c|c|}
\hline \multirow[b]{2}{*}{ Treatments } & \multicolumn{4}{|c|}{ 15th June 2019} & \multicolumn{4}{|c|}{ 15th September 2019} \\
\hline & $\begin{array}{c}\text { Nematode } \\
\text { population/ } \\
250 \mathrm{~g} \text { soil }\end{array}$ & $\begin{array}{l}\text { Percent of } \\
\text { decrease } \%\end{array}$ & $\begin{array}{c}\text { Adult female } \\
\text { population/g } \\
\text { of root }\end{array}$ & $\begin{array}{l}\text { Percent of } \\
\text { decrease \% }\end{array}$ & $\begin{array}{c}\text { Nematode } \\
\text { population/ } \\
\text { 250g soil }\end{array}$ & $\begin{array}{l}\text { Percent of } \\
\text { decrease \% }\end{array}$ & $\begin{array}{c}\text { Adult female } \\
\text { population/g } \\
\text { of root }\end{array}$ & $\begin{array}{l}\text { Percent of } \\
\text { decrease \% }\end{array}$ \\
\hline $\left.\mathrm{T}_{1}\right) M$. radiotolerans $(\mathrm{R} 1)_{+} \mathrm{F}$ & $1240 \mathrm{c}$ & 46 & $20 \mathrm{c}$ & 58.5 & $740 \mathrm{~cd}$ & 73.5 & $14.6 \mathrm{~b}$ & 72.7 \\
\hline $\left.\mathrm{T}_{2}\right)$ P. polymyxa $(\mathrm{R} 1)_{+} \mathrm{F}$ & $1172.3 \mathrm{c}$ & 49 & $16.6 \mathrm{c}$ & 65.6 & $680 \mathrm{de}$ & 75.7 & $10.6 \mathrm{de}$ & 80 \\
\hline $\left.\mathrm{T}_{3}\right)$ Humic acid $(\mathrm{R} 1)_{+} \mathrm{F}$ & $1500 \mathrm{~b}$ & 34 & $23.3 b$ & 51.7 & $1006.6 \mathrm{~b}$ & 64 & $15 \mathrm{~b}$ & 72 \\
\hline $\left.\mathrm{T}_{4}\right) \mathrm{T}_{1}+\mathrm{T}_{2+} \mathrm{F}$ & $1046.3 \mathrm{~d}$ & 54.5 & $16.6 \mathrm{~d}$ & 65.6 & $720 \mathrm{~cd}$ & 74 & $7.6 \mathrm{fgh}$ & 85.8 \\
\hline $\left.\mathrm{T}_{5}\right) \mathrm{T}_{1}+\mathrm{T}_{3+} \mathrm{F}$ & $1032.3 \mathrm{~d}$ & 55 & $14 \mathrm{de}$ & 71 & $673.3 \mathrm{de}$ & 75.9 & 10.3 ef & 80.7 \\
\hline $\left.\mathrm{T}_{6}\right) \mathrm{T}_{2}+\mathrm{T}_{3+} \mathrm{F}$ & $933.3 \mathrm{ef}$ & 59 & $13 \mathrm{ef}$ & 73 & 580 efg & 79 & $9.6 \mathrm{efg}$ & 82 \\
\hline $\left.\mathrm{T}_{7}\right) \mathrm{T}_{1+} \mathrm{T}_{2}+\mathrm{T}_{3+} \mathrm{F}$ & 1020de & 55 & $14.3 \mathrm{de}$ & 70 & $800 \mathrm{c}$ & 71 & $14.6 \mathrm{~b}$ & 72.7 \\
\hline $\left.\mathrm{T}_{8}\right) M$. radiotolerans $(\mathrm{R} 2)_{+} \mathrm{F}$ & $1020 \mathrm{de}$ & 55 & $10.6 \mathrm{fg}$ & 78 & $480 \mathrm{gh}$ & 82.8 & 7 ghi & 86.9 \\
\hline $\left.\mathrm{T}_{9}\right)$ P. polymyxa $(\mathrm{R} 2)_{+} \mathrm{F}$ & $900 f$ & 60.8 & $9.3 \mathrm{gh}$ & 80.7 & $400 \mathrm{~h}$ & 85.7 & $5.6 \mathrm{hi}$ & 89.5 \\
\hline $\left.\mathrm{T}_{10}\right)$ Humic acid $(\mathrm{R} 2)_{+} \mathrm{F}$ & $1212.3 \mathrm{c}$ & 47 & $10 \mathrm{~d}$ & 79 & $666.6 \mathrm{def}$ & 76 & $13.3 \mathrm{bcd}$ & 75 \\
\hline $\left.\mathrm{T}_{11}\right) \mathrm{T}_{8+} \mathrm{T}_{9+} \mathrm{F}$ & $900 f$ & 60.8 & $5.6 \mathrm{ij}$ & 88 & 580 efg & 79 & $14 \mathrm{bc}$ & 73.8 \\
\hline $\left.\mathrm{T}_{12}\right) \mathrm{T}_{8+} \mathrm{T}_{10+} \mathrm{F}$ & $900.3 f$ & 60.8 & 8.3 ghi & 82.8 & $553.3 \mathrm{fg}$ & 80 & 7.3 ghi & 86 \\
\hline $\left.\mathrm{T}_{13}\right) \mathrm{T}_{9}+\mathrm{T}_{10+} \mathrm{F}$ & $726.6 \mathrm{~g}$ & 68 & $8.6 \mathrm{gh}$ & 82 & $466.6 \mathrm{gh}$ & 83 & 6.3 hi & 88 \\
\hline $\left.\mathrm{T}_{14}\right) \mathrm{T}_{8+} \mathrm{T}_{9}+\mathrm{T}_{10+} \mathrm{F}$ & $766.6 \mathrm{~g}$ & 66.6 & 7.3 hij & 84.8 & 580 efg & 79 & $11.3 \mathrm{cde}$ & 79 \\
\hline $\left.\mathrm{T}_{15}\right)$ Nemathorin $\circledast 10 \% \mathrm{G}$ & $346.6 \mathrm{~h}$ & 85 & $5 \mathrm{j}$ & 89.6 & $240 \mathrm{i}$ & 91 & $4.6 \mathrm{i}$ & 91.4 \\
\hline $\mathrm{T}_{16}$ ) Control & $2300 \mathrm{a}$ & --- & $48.3 \mathrm{a}$ & -- & $2800 \mathrm{a}$ & -- & $53.6 \mathrm{a}$ & -- \\
\hline
\end{tabular}

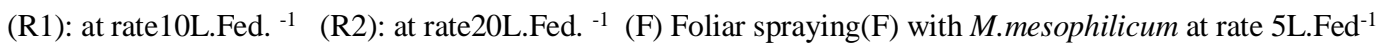

*Different letter(s) indicate significant differences among treatments within the same column according to Duncan's multiple range test $(\mathrm{P} \leq 0.05)$.

Efficacy of bio- agents on citrus nematode, T. semipenetrans infecting Balady orange trees in Sharkia Governorate.

Two bio- agents, namely $M$. radiotolerans and P.polymyxa and humic acid, alone and in combination treatments at two different rates in the presence of foliar spraying of $M$. mesophilicum were studied against citrus nematode, $T$. semipenetrans under field conditions. Data in Table (6) reveled that all treatments caused significant $\quad(\mathrm{P} \leq 0.05)$ reduction in $T$. semipenetrans numbers, compared to control treatment. Two months after the fourth application of these treatments (June, 2019), the nematicide, Nemathorin ${ }^{\circledR}$ $10 \% \mathrm{G}\left(\mathrm{T}_{15}\right)$ recorded the highest percentage of reduction in number of $\mathrm{J}_{2} / 250 \mathrm{~g}$ soil, and number of adult females/1g roots with values $90 \%$, and $92 \%$ respectively. The application of $P$. polymyxa at a rate of $20 \mathrm{~L}$. $\mathrm{fed}^{-1}+$ foliar spraying of $M$. mesophilicm at rate of $5 \mathrm{~L}$. fed $^{-1}$ $\left(\mathrm{T}_{9}\right)$, and the combination of $P$. polymyxa+ Humic acid+ $M$. radiotolerans at the rate
20L.Fed ${ }^{-1}$ in the presence of foliar spraying of M. Mesophilicum $\left(\mathrm{T}_{14}\right)$, recorded the same results in percentage of reduction in the number of $\mathrm{J}_{2} / 250 \mathrm{~g}$ soil $(76 \%)$, and the number of adult females/1g roots was $(87 \%)$.

Five months after the fourth application (September 2019), Nemathorin ${ }^{\circledR} \quad 10 \%$ G $\quad\left(\mathrm{T}_{15}\right)$ showed the highest efficacy in controlling the citrus nematode as indicated by the highest percentage reduction in the number of $J_{2} / 250 \mathrm{~g}$ soil $(90 \%)$, and the number of adult females/1g roots (94\%), followed by the application of The application of $P$. polymyxa at a rate of $20 \mathrm{~L}^{\text {. fed }}{ }^{-1}+$ foliar spraying of M. mesophilicm at rate of 5L. fed ${ }^{-1}\left(\mathrm{~T}_{9}\right)$ with percentage reduction in the number of $\mathrm{J}_{2} / 250 \mathrm{~g}$ soil $(87 \%)$, and the number of adult females/1g roots $(90 \%)$. While, the third most effective treatment in percentage reduction in the number of $\mathrm{J}_{2} / 250 \mathrm{~g}$ soil, and the number of adult females/1g roots was the combination of $P$. polymyxa+ Humic acid at rate of $20 \mathrm{~L}^{- \text {fed }^{-1}}+$ foliar spraying of M. mesophilicm at rate of $5 \mathrm{~L} . f e d^{-1}\left(\mathrm{~T}_{13}\right)$ with values of $85 \%$ and $89 \%$ respectively. 
Table 6. Efficacy of biocontrol agents and humic acid alone and in combination, at two different rates with foliar spraying of Methylobacterium mesophilicm against citrus nematode, $T$. semipenetrans on Balady orange trees in Sharkia Governorate under field conditions

\begin{tabular}{|c|c|c|c|c|c|c|c|c|}
\hline \multirow[b]{2}{*}{ Treatments } & \multicolumn{4}{|c|}{ 15th June 2019} & \multicolumn{4}{|c|}{ 15th September 2019} \\
\hline & $\begin{array}{c}\text { Nematode } \\
\text { population/ } \\
250 \mathrm{~g} \text { soil }\end{array}$ & $\begin{array}{r}\text { Percent of } \\
\text { decrease \% }\end{array}$ & $\begin{array}{c}\text { Adult female } \\
\text { population/ } \mathrm{g} \\
\text { of root }\end{array}$ & $\begin{array}{r}\text { Percent of } \\
\text { decrease \% }\end{array}$ & $\begin{array}{c}\text { Nematode } \\
\text { population/ } \\
250 \mathrm{~g} \text { soil }\end{array}$ & $\begin{array}{r}\text { Percent of } \\
\text { decrease } \%\end{array}$ & $\begin{array}{c}\text { Adult female } \\
\text { population/ } \mathrm{g} \\
\text { of root }\end{array}$ & $\begin{array}{r}\text { Percent of } \\
\text { decrease \% }\end{array}$ \\
\hline $\left.\mathrm{T}_{1}\right) M$. radiotolerans $(\mathrm{R} 1)_{+} \mathrm{F}$ & $1153.3 \mathrm{~cd}$ & 60 & $22.3 b$ & 58 & $606.6 \mathrm{~cd}$ & 81 & $14.6 b$ & 74 \\
\hline $\left.\mathrm{T}_{2}\right)$ P. polymyxa $(\mathrm{R} 1)_{+} \mathrm{F}$ & $1133.3 \mathrm{~cd}$ & 60 & $20.3 b$ & 61 & $623.3 \mathrm{~cd}$ & 80 & $10.6 \mathrm{~cd}$ & 81 \\
\hline $\left.\mathrm{T}_{3}\right)$ Humic acid $(\mathrm{R} 1)_{+} \mathrm{F}$ & $1413.3 b$ & 51 & $20.3 b$ & 61 & $1006.6 b$ & 68 & $15 b$ & 73 \\
\hline $\left.\mathrm{T}_{4}\right) \mathrm{T}_{1}+\mathrm{T}_{2+} \mathrm{F}$ & $1153.3 \mathrm{~cd}$ & 60 & 12.6def & 76 & $720 \mathrm{bcd}$ & 77 & 7.6efg & 87 \\
\hline $\left.\mathrm{T}_{5}\right) \mathrm{T}_{1}+\mathrm{T}_{3}+\mathrm{F}$ & $1160 \mathrm{~cd}$ & 60 & $12 \mathrm{efg}$ & 77 & $673.3 \mathrm{bcd}$ & 79 & $10.3 \mathrm{de}$ & 82 \\
\hline $\left.\mathrm{T}_{6}\right) \mathrm{T}_{2}+\mathrm{T}_{3+} \mathrm{F}$ & 1073.3de & 63 & $15.6 \mathrm{~cd}$ & 70 & $580 \mathrm{~cd}$ & 82 & 9.6def & 83 \\
\hline $\left.\mathrm{T}_{7}\right) \mathrm{T}_{1+} \mathrm{T}_{2}+\mathrm{T}_{3+} \mathrm{F}$ & $1220 \mathrm{c}$ & 57 & $16.6 \mathrm{c}$ & 68 & 800 bc & 75 & $14.6 \mathrm{~b}$ & 74 \\
\hline $\left.\mathrm{T}_{8}\right) M$. radiotolerans $(\mathrm{R} 2)_{+} \mathrm{F}$ & $820 \mathrm{gh}$ & 71 & $10.6 \mathrm{fgh}$ & 80 & $680 \mathrm{bcd}$ & 79 & $10.6 \mathrm{~cd}$ & 81 \\
\hline $\left.\mathrm{T}_{9}\right)$ P. polymyxa $(\mathrm{R} 2)_{+} \mathrm{F}$ & $693.3 h$ & 76 & $7 \mathrm{ijk}$ & 87 & $400 \mathrm{~d}$ & 87 & $5.6 \mathrm{gh}$ & 90 \\
\hline $\left.\mathrm{T}_{10}\right)$ Humic acid $(\mathrm{R} 2)_{+} \mathrm{F}$ & $1213.3 c$ & 58 & $15 \mathrm{cde}$ & 71 & $530 \mathrm{~cd}$ & 83 & $13.3 \mathrm{bc}$ & 76 \\
\hline $\left.\mathrm{T}_{11}\right) \mathrm{T}_{8+} \mathrm{T}_{9+} \mathrm{F}$ & 960 ef & 67 & 9ghi & 83 & $620 \mathrm{~cd}$ & 80 & $8.6 \mathrm{def}$ & 84 \\
\hline $\left.\mathrm{T}_{12}\right) \mathrm{T}_{8+} \mathrm{T}_{10+} \mathrm{F}$ & $766.6 \mathrm{gh}$ & 73 & 9ghi & 83 & $573.3 \mathrm{~cd}$ & 82 & $7.3 \mathrm{fg}$ & 87 \\
\hline $\left.\mathrm{T}_{13}\right) \mathrm{T}_{9}+\mathrm{T}_{10+} \mathrm{F}$ & $833.3 \mathrm{fg}$ & 71 & $9.3 \mathrm{ghi}$ & 82 & $480 \mathrm{~cd}$ & 85 & $6.3 \mathrm{~g}$ & 89 \\
\hline $\left.\mathrm{T}_{14}\right) \mathrm{T}_{8+} \mathrm{T}_{9}+\mathrm{T}_{10+} \mathrm{F}$ & $700 \mathrm{~h}$ & 76 & $7 \mathrm{ijk}$ & 87 & $480 \mathrm{~cd}$ & 85 & $7 \mathrm{fg}$ & 88 \\
\hline $\mathrm{T}_{15}$ ) Nemathorin ${ }^{\circledR} 10 \% \mathrm{G}$ & $286.6 \mathrm{i}$ & 90 & $4.3 \mathrm{k}$ & 92 & $320 \mathrm{e}$ & 90 & $3.3 \mathrm{~h}$ & 94 \\
\hline $\mathrm{T}_{16}$ ) Control & 2866.6 & -- & 52.6 & -- & 3166.6 & -- & 56.3 & -- \\
\hline
\end{tabular}

(R1): at rate10L.Fed. ${ }^{-1}$ (R2): at rate20L.Fed. ${ }^{-1}$ (F) Foliar spraying(F) with M.mesophilicum at rate 5L.Fed ${ }^{-1}$

*Different letter(s) indicate significant differences among treatments within the same column according to Duncan's multiple range test $(\mathrm{P} \leq 0.05)$.

Management of plant-parasitic nematodes are difficult in particular under field conditions due to the optimal growing conditions in citrus orchards (soil moisture and temperature) most of the year (Díez and Dusenbery, 1989). Regardless of their fast- acting, nematicides may be harmful to both human and environment. The bio-agents or soil amendments are alternative methods in controlling plant parasitic nematodes.Since,the results of this study demonstrated a major advanced in controlling of the citrus nematode, $T$. semipenetrans with all the tested treatments under field conditions. It may be due to bacterial products like antibiotics and secondary metabolites such as protease, $\mathrm{HCN}$ and chitinase production. The toxic effect of $\mathrm{HCN}$ on the nematodes is consistent with the loss of mitochondrial function through the inhibition of cytochrome c oxidase (Zdor, 2015), or the sequestration of Fe from the host cells due to the formation of $\mathrm{FeCN}$ (Rijavec and Lapanje, 2016).

The current study proved that $P$. polymyxa has the ability to produce chitinase enzyme.
The production of lytic enzymes may be playing an important role in the reduction of $T$. semipenetrans populations. Many investigators studied the effect of chitinase production in reducing the nematode population, Jung et al. (2002) determined that Paenibacillus illinoisensis KJA-424 a chitinase-producing bacterium causes $M$. incognita egg shell lysis, particularly in the early juvenile stage, resulting in egg hatching inhibition and/or egg kill. Chitinolytic activity lysis plays a role in regulating root-knot nematode $M$. incognita.

Jha et al. (2015) illustrated that Methylobacterium induce systemic resistance by production of proteins like phenylalanine ammonia lyase, peroxidase, chitinase and $\beta-1$, 3-glucanase and phenolic compounds. On the other hand, the microbial protease may contribute to infection of hosts by degrading the host's protective barriers (Ahman et al., 2002and Huang et al., 2004). It has also been shown that bacterial proteases can degrade and digest nematode cuticle or even kill hosts. The extracellular protease from nematophagous fungi inhibits nematode infection by degrading 
cuticle proteins (Morton et al., 2004). The results were further supported by the findings of Denizci et al. (2004) and Lian at al. (2007) who reported that antagonism of Bacillus species related to the production of protease.

Using low-molecular-weight organic acids is another strategy to manage plant-parasitic nematodes (Browning et al., 2006). Many organic acids produced during the decomposition of organic matter exhibit nematicidal activity (Mian \& RodriguezKabana 1982and Renco et al., 2012). Humic acid typically contains hetero cyclic compounds with carboxylic, phenol and carbonyl functional groups. Because of the nature of their functional groups, it is possible that humic acids may have lethal effects on nematodes too. Many investigators reported the role of humic acid against root-knot nematode, Saravanapriya \& Subramanian (2007) reported that soil amended with humic acid significantly decreased the number of galls, and egg masses/plant and soil populations of M.incognita in tomato. Similarly, Seenivasan \& Senthilnathan (2017) showed that hatching of $M$. incognita eggs was inhibited byb50\%$100 \%$ following incubation in $0.08 \%-2.0 \%$ humic acid in vitro. Exposure of juveniles $\left(\mathrm{J}_{2}\right)$ of $M$. incognita to different humic acid concentrations significantly affected the mobility of $\mathbf{J}_{2}$ in vitro, also humic acid improves growth of the banana.

In the current study, the combination of $P$. polymyxa with humic acid was more effective in reducing the population of citrus nematode in soil and roots, this may be due to the addition of humic acid to soil stimulates the growth of rhizosphere bacteria and actinomycetes (Vallini et al., 1993). As well, Fallah et al. (2012) reported that humic acid improved the growth of Azotobacter chroococcum and A. vinelandii.

Effect of biocontrol agents and humic acid on Balady orange fruit yield under field conditions in Ismailia and Sharkia Governorates

Effect of the two biocontrol agents, $(M$. radiotolerans $+P$. polymyxa), and humic acid alone, and in combination, at two rates+foliar spraying of M.mesophilicum was evaluated on Balady orange fruit yield under field conditions in Ismailai and Sharkia Governorates. Results in Table (7) revealed to all treatments increased the fruit yield compared to control treatment. The nematicide Nemathorin ${ }^{\circledR} 10 \% \quad G \quad\left(T_{15}\right)$ gave the highest fruit yield/ tree as well as the average of fruit weight (g), followed by the combined treatment of P.polymyxa+ Humic acid at rate of 20L.Fed ${ }^{-1}+$ foliar spraying of M.mesophilicum $\left(\mathrm{T}_{13}\right)$. The highest percentage increase in fruit yield were $(160 \%$ and206\%), $(155.7 \%$ and $193 \%)$, and (153\% and $182 \%)$ with Nemathorin ${ }^{\circledR} \quad 10 \% \quad \mathrm{G} \quad\left(\mathrm{T}_{15}\right)$, treatment P.polymyxa + Humic acid at rate of $20 \mathrm{~L} . \mathrm{Fed}^{-1}+$ foliar spraying of of M. mesophilicum $\left(\mathrm{T}_{13}\right)$, treatment and $M$. radiotolerans $+P$. polymyxa + foliar spraying of $M$. mesophilicum treatment $\left(\mathrm{T}_{11}\right)$, respectively in Ismailai, and Sharkia Governorates respectively.

In this respect Shehata et al. (2006) reported that, foliar application of PPFM in the presence of specific rhizobial inoculation scored significant increases in economic turnover of chickpea in the range of $21-32 \%$ as compared to $\mathrm{N}$-fertilization. Madhiayan et al. (2006) also stated that, application of $30 \%$ of methanol or PPFMs as a foliar spray significantly increased plant height, plant dry weight, leaf area, boll number and boll dry weight leading to an increase of seed cotton yield over control. Foliar applications with $20 \%$ of methanol with PPFMs 3or 4 spraying times gave the significantly higher values of cotton growth and yield parameters (AlMohamed et al., 2009).

The benefits of humate application to plants, including increases in soil water retention, growth of beneficial soil microorganisms (especially if exposed to contaminant toxicity), root respiration enzyme activity, root growth, and plant yield (Ouni et al., 2014). In addition, humic acid increases root growth up to $53 \%$ and facilitates more efficient nutrient absorption, it is obvious that the application of humic acid results in higher root growth and nutrient uptake in grape (Kesba and Hossam, 2012). 
Table 7. Effect biocontrol agents alone and in combination with humic acid with foliar spraying of $M$. mesophilicm on fruit yield of Balady orange infected with citrus nematode, $T$. semipenetrans under field conditions

\begin{tabular}{|c|c|c|c|c|c|c|}
\hline \multirow[b]{2}{*}{ Treatments } & \multicolumn{3}{|c|}{$\begin{array}{c}\text { Fruit yield, in Ismailia Governorate, } \\
\text { season } 2019\end{array}$} & \multicolumn{3}{|c|}{$\begin{array}{c}\text { Fruit yield, in Sharkia Governorate, } \\
\text { season } 2019\end{array}$} \\
\hline & $\begin{array}{l}\text { Number of } \\
\text { fruit/tree }\end{array}$ & $\begin{array}{c}\text { Fruit } \\
\text { weight (g) }\end{array}$ & $\begin{array}{c}\text { Percent } \\
\text { increase in } \\
\text { fruit yield\% }\end{array}$ & $\begin{array}{l}\text { Number of } \\
\text { fruit / tree }\end{array}$ & $\begin{array}{c}\text { Fruit } \\
\text { weight }(\mathrm{g})\end{array}$ & $\begin{array}{c}\text { Percent } \\
\text { increase in } \\
\text { fruit yield\% }\end{array}$ \\
\hline $\left.\mathrm{T}_{1}\right) M$. radiotolerans $(\mathrm{R} 1)_{+} \mathrm{F}$ & $324.3 \mathrm{k}$ & $164 d$ & 15.5 & $384.3 \mathrm{i}$ & $163.3 d$ & 49 \\
\hline $\left.\mathrm{T}_{2}\right) P$. polymyxa $(\mathrm{R} 1)_{+} \mathrm{F}$ & $355.6 \mathrm{j}$ & 175 abcd & 26.7 & $392.3 \mathrm{i}$ & $185 \mathrm{ab}$ & 52 \\
\hline $\left.\mathrm{T}_{3}\right)$ Humic acid $(\mathrm{R} 1)_{+} \mathrm{F}$ & $411.3 \mathrm{i}$ & $171 \mathrm{abcd}$ & 46.5 & $434.6 \mathrm{~h}$ & $188.3 \mathrm{a}$ & 69 \\
\hline $\left.\mathrm{T}_{4}\right) \mathrm{T}_{1}+\mathrm{T}_{2}+\mathrm{F}$ & $481 \mathrm{~g}$ & $166.6 \mathrm{~cd}$ & 71.4 & $491 \mathrm{~g}$ & $177.3 \mathrm{abc}$ & 91 \\
\hline $\left.\mathrm{T}_{5}\right) \mathrm{T}_{1}+\mathrm{T}_{3+} \mathrm{F}$ & $442 \mathrm{~h}$ & 175 abcd & 57.5 & $465.3 \mathrm{~g}$ & $178.3 \mathrm{abc}$ & 81 \\
\hline $\left.\mathrm{T}_{6}\right) \mathrm{T}_{2}+\mathrm{T}_{3+} \mathrm{F}$ & $488.6 \mathrm{~g}$ & $169.6 \mathrm{bcd}$ & 74 & $532 f$ & $169.6 \mathrm{~cd}$ & 107 \\
\hline $\left.\mathrm{T}_{7}\right) \mathrm{T}_{1+} \mathrm{T}_{2}+\mathrm{T}_{3+} \mathrm{F}$ & $526.3 \mathrm{f}$ & $171.3 \mathrm{abcd}$ & 87.5 & $536.3 \mathrm{f}$ & $185.6 \mathrm{ab}$ & 108 \\
\hline $\left.\mathrm{T}_{8}\right) M$. radiotolerans $(\mathrm{R} 2)_{+} \mathrm{F}$ & $629.3 \mathrm{~d}$ & $180.3 \mathrm{abc}$ & 124 & $652.6 \mathrm{~d}$ & $1843 \mathrm{ab}$ & 154 \\
\hline $\left.\mathrm{T}_{9}\right) P$. polymyxa $(\mathrm{R} 2)_{+} \mathrm{F}$ & $697 \mathrm{~b}$ & $180 \mathrm{abc}$ & 148 & $697 \mathrm{c}$ & $180 \mathrm{abc}$ & 171 \\
\hline $\left.\mathrm{T}_{10}\right)$ Humic acid $(\mathrm{R} 2)_{+} \mathrm{F}$ & $576.3 \mathrm{e}$ & $167 \mathrm{~cd}$ & 105 & $576.3 \mathrm{e}$ & $169.3 \mathrm{~cd}$ & 124 \\
\hline $\left.\mathrm{T}_{11}\right) \mathrm{T}_{8+} \mathrm{T}_{9+} \mathrm{F}$ & $711.3 \mathrm{ab}$ & $174.3 \mathrm{abcd}$ & 153 & $724.3 \mathrm{bc}$ & $183 \mathrm{abc}$ & 182 \\
\hline $\left.\mathrm{T}_{12}\right) \mathrm{T}_{8+} \mathrm{T}_{10+} \mathrm{F}$ & $659.6 \mathrm{c}$ & $172.6 \mathrm{abcd}$ & 135 & $659.6 \mathrm{~d}$ & $172.6 \mathrm{bcd}$ & 156 \\
\hline $\left.\mathrm{T}_{13}\right) \mathrm{T}_{9}+\mathrm{T}_{10+} \mathrm{F}$ & $717.6 \mathrm{ab}$ & $185 \mathrm{a}$ & 155.7 & $754.6 \mathrm{~b}$ & 175.6abcd & 193 \\
\hline $\left.\mathrm{T}_{14}\right) \mathrm{T}_{8+} \mathrm{T}_{9}+\mathrm{T}_{10+} \mathrm{F}$ & $632.6 \mathrm{~d}$ & $182.3 \mathrm{ab}$ & 125 & $646 \mathrm{~d}$ & $173.6 \mathrm{bcd}$ & 151 \\
\hline $\left.\mathrm{T}_{15}\right)$ Nemathorin $® 10 \% \mathrm{G}$ & $731 \mathrm{a}$ & 185 a & 160 & $787.6 \mathrm{a}$ & $184.3 \mathrm{ab}$ & 206 \\
\hline $\mathrm{T}_{16}$ ) Control & 280.61 & $137.3 \mathrm{e}$ & -- & $257.3 \mathrm{j}$ & $147.3 \mathrm{e}$ & -- \\
\hline
\end{tabular}

(R1): at rate10L.Fed. ${ }^{-1}(\mathrm{R} 2)$ : at rate20L.Fed. ${ }^{-1}(\mathrm{~F})$ Foliar spraying(F) with M. mesophilicum at rate 5L.Fed ${ }^{-1}$

*Different letter(s) indicate significant differences among treatments within the same column according to Duncan's multiple range test $(\mathrm{P} \leq 0.05)$.

\section{REFERENCES}

Abdel-Baset, H. Sahar and Hend, M.A. El-Egami (2019). Effect of Some Bio-Fertilizers on the RootKnot Nematode Meloidogyne incognita Infecting Common Bean (Phaseolus vulgaris L.). Int. J. Microbiol. Res. 10: 148-157.

Abd-Elgawad, M.M. (1992). Spatial distribution of the phytonematode community inEgyptian citrus groves. Fund. \& Appl. Nematol., 15: 367-373.

Abd-Elgawad, M.M. (2013). Phytonematode damage, economic threshold and management with special reference to Egypt. Egypt. J. Agronematol., 12(1): 159-176.

Ahmed, A. and Hasnain, S. (2010). Auxinproducing Bacillus sp.: auxin quantification and effect on the growth of Solanum tuberosum. Pure and Appl. Chemist., 82:313-319.

Ahman, J.; Johansson, T.; Olsson, M.; Punt, P.J.; Van Den Hondel, C.A.M.J.J. and Tunlid, A.
(2002). Improving the pathogenicity of a nematode trapping fungus by genetic engineering of a subtilisin with nematotoxic activity. Appl. Environ. Microbiol. 68: 3408-3415.

Al-Mohamed, H. Kenda, Fayed, T. B.; Mostafa, M.T., Sliem, Sh. M. and Saudy, H.S. (2009). Preliminary studies on the effect of foliar application of methanol and pink pigmented facultative methylotrophic bacteria on cotton plant. Arab Univ. J. Agric. Sci. Ain Shams, Univ., Cairo, 17 (1):57-63.

Anonymous, S.A. (1991). A Software Program for the MSTAT-C Design, Management and Analysis of Agronomic Research Experiments. Michigan State Univ.

Anwar-ul-Haq M.; Anwar, S.A.; Shahid, M.; Javed, N.; Khan, A.S. and Mehamood, K. (2011). Management of root knot nematode Meloidogyne incognita by plant growth promoting rhizobacterial on tomato. Pakist. J. Zool., 43:1027-1031. 
Ardanov, P.; Sessitsch, A.; Haggman, H.; Kozyrovska, N. and Pirttila, A.M. (2012). Methylobacterium induced endophyte community changes correspond with protection of plants against pathogen attack. PLoS ONE 7:10 Article ID e46802.

Ashraf, M. A.; Muhammad, A.; Ahmad, Z.; Arif, M.; Qasim, A. and Mahmood, R. (2013). Plant growth promoting rhizobacteria and sustainable agriculture: A review. African J. Microbiol. Res., 9: 704-709.

Ayoub, S.M. (1980). Plant nematology, an agricultural training aid. Secramanto, California, USA, Nema aid Publications, p 195.

Badawi, F.Sh.F.; Biomy, A.M.M. and desoky, A.H. (2011). Peanut plant growth and yield as influenced by co-inoculation with Bradyrhizobium and some rhizo-microorganisms under sandy loam soil conditions. Annal. Agric. Sci., 56:17-25.

Bakker, A.W. and Schippers, B. (1987). Microbial cyanide production in the rhizosphere in relation to potato yield reduction and Pseudomonas sp. mediated plant growth stimulation. Soil Boil. Biochem., 4: 451-457.

Baklawa, M. H. (2004). Pathological and biological studies on nematodes infecting fruit trees. M. Sc. Thesis, Faculty of Agric., Suez Canal Univ., pp. 181

Brick, J.M.; Bostock, R.M. and Silverstone, S.E. (1991). Rapid in situ assay for indole acetic acid production by immobilized on a nitro cellulose membrane. Appl. Environ. Microbiol., 57: 535-538.

Browning, M.; Wallace, D.B.; Dawson, C.; Alm, S.R. and Amador, J.A. (2006). Potential of butyric acid for control of soil-borne fungal pathogens and nematodes affecting strawberries. Soil Biol Biochem., 38:401-404.

Byrd, D.W.; Kirkpatrick, T. and Barker, K. (1983). An improved technique for clearing and staining plant tissues for detection nematodes. J. Nematol., 15: 142-143.

Castaneda-Alvarez, C. and Aballay, E. (2016). Rhizobacteria with nematicide aptitude: Enzymes and compounds associated. World J. Microbiol. \& Biotechnol., 32: 137.

Denizci, A.A.; Kazen, D.; Abeln, E.C.A. and Erarslan, A. (2004). Newly Isolated Bacilus clausi GMBAE 42: an alkaline protease producer capable to grow under highly alkaline conditons. J. Appl. Microbiol., 96: 320-327.

Diez, J. A. and Dusenbery, D. B. (1989). Preferred temperature of Meloidogyne incognita. J. Nematol., 21:99-104.

Dowson, W.J. (1957). Plant disease due Bacteria. Seconded., Cambridge, The university press, London, pp. 231.
Duncan, D. B. (1955). Multiple range and multiple F tests. Biometrics. 11: 1-42.

Duncan, L. W. (1999). Nematode diseases of citrus. Pp. 136-148 in L. W. Timmer and L. W. Duncan, eds. Citrus health management. St. Paul, MN: APS Press.

Duncan, L.W. (2005). Nematode parasites of citrus. In: Luc, M. Sikora, R. A. \& Bridge, J. (Eds.). Plant Parasitic Nematodes in Subtropical and tropical Agriculture, 2th edition: Wallingford, U.K. CABI Publishing, pp. 593-607.

Duncan L.W. and Cohn, E. (1990). Nematode parasites of citrus. In 'Plant Parasitic Nematodes in Subtropical and Tropical Agriculture' Luc, R. A. Sikora and Bridge, eds), CAB International, Wallingford, UK, pp. 321-346.

Dunne, C.; Crowley, J.J.; Moenne-Loccoz, Y.; Dowling, D.N.; de-Bruijn, F.J. and O'Gara, F. (1997). Biological control of Pythium ultimum by Stenotrophomonas maltophilia W81 is mediated by an extracellular protiolytic avtivity. Microbiol., 143: 3921-3931

El-Banhawy, E.M.; Nasr, A.K. and Afia, S.I., (2006). Survey of predacious soil mites (Acari: Mesostigmata) in citrus orchards of the Nile Delta and Middle Egypt with notes on the abundance of the citrus parasitic nematode Tylenchulus semipenetrans (Tylenchida: Tylenchulidae). Intern. J. Trop. Insect Sci., 26(1), pp.64-69.

El-Mohamedy, R.S.R.; Hammam, M.M.A; AbdEl-Kareem, F. and Abd-Elgawad, M.M.M. (2016). Biological soil treatment to control Fusarium solani and Tylenchulus semipenetrans on sour orange seedlings under greenhouse conditions. Int. J. ChemTech Res, 9(7): 73-85. 10.

El-Sayed, Y.S. Soad, Hend, M. E. and ElTahlawy, Y.A. (2016). Symbiotic $\mathrm{N}_{2}$-fixation efficiency of lupine plant under fungal and bacterial inoculation. Egypt. J. Biotechnol. 52:107-122.

Fallah Q.M.; Habib, I.D.; Pazoki, A.R. and Khavazi, K. (2012). Effect of some Azotobacter chroococcum species and humic acid on production of auxin hormone, yield and yield components of wheat under different nitrogen levels. Iranian $\mathrm{J}$. Agron. Pl Breeding. 8:97-109.

Gao, H.; Qi, G.; Yin, R.; Zhang, H.; Li, C. and Zhao, X. (2016). Bacillus cereus strain S2 shows high nematicidal activity against Meloidogyne incognita producing sphingosine. Scientific Reports, 6. Pp 605.

Glick, B.R. (2012). Plant Growth-Promoting Bacteria: Mechanisms and Applications Hindawi Publishing Corporation Scientifca, ArticleI D963401,15pages. 
Goldstein, A.H.; Lester, T. and Brown, J. (2003). Research on the metabolic engineering of the direct oxidation pathway for extraction of phosphate from ore has generated preliminary evidence for PQQ biosynthesis in Escherichia coli as well as a possible role for the highly conserved region of quinoprotein dehydrogenases. Biochimica Biophysica Acta 1647:266-271.

Hammam, M.M.A.; El-Mohamedy, R.S.R.; AbdEl-Kareem, F. and Abd-Elgawad, M.M.M. (2016). Evaluation of soil amended with bio-agents and compost alone or in combination for controlling citrus nematode Tylenchulus semipenetrans and Fusarium dry root rot on Volkamer lime under greenhouse conditions. Int. J. ChemTech Res., 9(7): 86-96.

Hang, Y.W.; Byung, Y.K.; Jae, H.J.; Jung, A.S.; Myung, H.S.; Soon, W.K.; Seung, J.G. and Sang, H.Y. (2008). Methylobacterium iners sp. nov. and Methylobacterium aerolatum sp. nov., isolated from air samples in korea. Int. J. System. Evaluation. Microbiol. 58: 93-96.

Hemlata, C.; Bagyaraj, G.; Selvakumar, G. and Sundaramc, S.P. (2015). Novel plant growth promoting rhizobacterial. App. Soil Ecology, 95: 3853.

Holland, M.A. (1997). Methylobacterium and plants. Recent Res. Develop. Plant Physiol., 1:207213.

Holland, M. A. and Polacco, J. C. (1992). Urease null and hydrogenase - null phenotypes of a phylloplane bacterium reveal altered nickel metabolism in two soybean mutants. Plant Physiol. 98: 942-948.

Holland, M. A.; Long, R.L.G. and Polacco, J.C. (2002). Methylobacterium spp.: phylloplane bacteria involved in cross talk with the plant host. In: Lindow, S. E., E. I. Hecht-Poinar and V. J. Elliot (Eds.), Phyllosphere Microbiology. APS, St Paul, Minn., pp.125-135.

Huang, X.W.; Zhao, N.H. and Zhang, K.Q. (2004). Extracellular enzymes serving as virulence factors in nematophagous fungi involved in infection of the host. Res. Microbiol. 155: 811-816.

Ibrahim, I.K.A. (1994). Potentially important phytoparasitic nematodes in agroforestry plantations and the associated host plants. In 1. International Symposium on Silviculture of Protection Foresty in Arid Regions and the Agroforestry Potential, Alexandria (Egypt).

Ivanova, E. G.; Doronina, N. V.; Shepeliakovskaia, A. O.; Laman, A.G.; Brovko, F. A. and Yu. A. Trotsenko (2000). Facultative and obligate aerobic methylobacteria synthesize cytokinins. Microbiol., 69: 764-769.
Jackson, M.L. (1973). Soil Chemical Analysis. Prentice-Hall India Private limited, New Delhi.

Jha, C.K.; Annapurna, K. and Saraf, M. (2012). Isolation of rhizobacteria from jatropha curcas and characterization of produced ACC deaminase. J. Basic Microbiol., 52:285-295

Jha, C.K.; Maheshwari, D.K. and Saraf, M. (2015) Emergence of Methylobacterium spp. as Potential Organism in Agroecosystems. In: Maheshwari D. (eds) Bacterial Metabolites in Sustainable Agroecosystem. Sustainable Development and Biodiversity, vol 12. Springer, Cham.

Jha, C.K.; Patel, D.; Rajendran, N. and Saraf, M. (2010). Combinatorial assessment on dominance and informative diversity of PGPR from rhizosphere of Jatropha curcas L. J. Basic Microbiol., 50:211-217.

Jung, S.J.; An, K.N.; Jin, Y.L.; Park, R.D.; Kim, K.Y.; Shon, B.K. and Kim, T.H. (2002). Effect of chitinase-producing Paenibacillus illinoisensis KJA424 on egg hatching of root-knot nematode (Meloidogyne incognita). J. Microbiol. Biotechnol., 12(6): 865-871

Khan M.R. (2007). Prospects of microbial control of root-knot nematodes infecting vegetable crops. In: Boitechnology: Plant Health Management (Sharma N. and Singh H.B., eds). International Book Distributing Co., Lucknow, India. Pp. 643-665.

Khan, M.R.; Altaf, S.; Mohidin, F.; Khan, U. and Anwer, A. (2009). Biological control of plant nematodes with phosphate solubilizing microorganisms. Phosphate Solubilizing Microbes for Crop Improvement. 395-426.

Khan M.R.; Khan, M.M.; Anwer, M.A. and Haque, Z. (2012). Laboratory and field performance of some soil bacteria used as seed treatments on Meloidogyne incognita in chickpea. Nematol. Medit., 40: 143-151.

Kesba, Hosny H. and Hossam S. E. (2012). Biochemical changes in grape rootstocks resulted from humic acid treatments in relation to nematode infection." Asian Pacific J. tropical biomedicine, 4: 287-293.

Kim J.W. (2016). Biological control of the RootKnot Nematode (Meloidogyne incognita): The development of a nematicide fertilizer using natural products. (jin.kim@wur.nl).

Koch, E.; Meier, B.M.; Eiben, H.G. and Slusarenko, A. (1992). A lipoxygenase from leaves of tomato (Lycopersicom esculentum Mill) is induced in response to plant pathogenic Pseudomonas. Plant Physiol., 99: 571-576.

Lian, L.H.; Tian, B.Y.; Xiong, R.; Zhu, M.Z.; Xu, J. and Zhang, K.Q. (2007). Protease from Bacilus: a new insight into the mechanism of action for 
rhizobacteria supresion of nematode population. Lett. Appl. Microbiol., 45: 262-269.

Lugtenberg, B. and Kamilova, F. (2009). Plant growth-promoting rhizobacterial. Annu. Rev. Microbiol., 63: 541-556.

Madhiayan, M.; Poonguzhali, S.; Senthilkumar, M.; Seshadri, S.; Chung, H.; Yang, J.; Sundaram, S. and Tongmin, S.A. (2004). Growth promotion and induction of systemic resistance in rice cultivar Co-47 Oryza sativa L.by Methylobacterium spp. Bot. Bull. Acad. Sin.,45:315-324.

Madhiayan, M.; Poonguzhali, S.; Lee, H.S.; Hari, K.; Sundaram, S.P. and Sa, T.M. (2005). Pink pigmented facultative methylotrophic bacteria accelerate germination, growth and yield of sugercane clone Co86032 (Saccarm officinarium L.). Biol. Fertil. Soils, 41(5): 350-358.

Madhiayan, M.; Poonguzhali, S.; Sundaram, S.P. and Sa, T.M. (2006). A new insight to foliar applied methanol influencing phylloplane methylotrophic dynamics and growth promotion of cotton (Gossypium hirsutum L.) and sugercane(Saccarm officinarium L.). Environ. Exp. Bot.,57:168-176.

Mai, W. F. and Lyon, H. H. (1975): Pectoral key to genera of plant- parasitic nematodes. Cornell Univ. Press. Thecae, New York nematodes. Wiley, New York, pp. 268.

Mian, I.H. and Rodriguez-Kabana, R. (1982). Survey of the nematicidal properties of some organic materials available in Alabama as amendments to soil for control of Meloidogyne arenaria. Nematrop., $12: 235-246$.

Martinez, O. V.; Jorquera, M.A.; Crowley, D.E.; Gajardo, G. and Mora, M.L. (2010). Mechanisms and practical considerations involved in plant growth promotion by rhizobacterial. J. Soil Sci. Plant Nutr., 3: 293-319.

Mayhew, L. (2004). Humic substances in biological agriculture. Acres 34, 1-2.

Mena, J. and Pimentel, E. (2002). Mechanism of action of Corynebacterium pauronetabolum strain C-924 on nematodes. Nematol., 4:287.

Meena, K.S.; Jonathan, E.I.; Devrajan, K. and Raguchander, T. (2012). Pseudomonas fluorescens induced systemic resistance in tomato against Meloidogyne incognita. Indian J. Nematol., 42: 510.

Meyer, S.L.F. (2003). United States Department of Agriculture - Agricultural Research Service research programs on microbes for management of plantparasitic nematodes. Pest Manag. Sci., 59: 665-670.

Mhatre, P.; Pankaj, H.; Kumar, J.; Shakil, N.A.; Kumar, R. and Adak, T. (2017). New formulations of salicylic acid and their bioefficacy evaluation on wheat against cereal cyst nematode. Indian J. Nematol., 47: 155-165.

Morton, C.O.; Hirsch, P.R. and Kerry, B.R. (2004). Infection of plant-parasitic nematodes by nematophagous fungi: a review of the application of molecular biology to understand infection processes and to improve biological control. Nematol., 6: 161170.

Neelakantan, S.; Mishra, M.M.; Tewari, H.K. and Vyas, N.R. (1970). Characterisation and microbial utilization of humic acid in Hissar soil. Agrochimica., 14: 341-344.

Norton, D.C. (1978). Ecology of plant parasitic nematodes. Wiley, N.Y., p.268.

Omer, Z.S.; Tombolini, R.; Broberg, A. and Gerhardson, B. (2004). Indole -3-acid production by pink pigmented facultative methylotrophic bacteria.Plant Growth Regul., 43: 93-96.

Orf, Heba O. M.; Wedad, E. E. Eweda; Sawsan, F. Shehata and Abo Taleb, H. H. (2005). Isolation, purification and identification of some microorganisms produce plant growth promoting substances (methylotrophic bacteria). Arab Univ. J. Agric. Sci. Ain Shams, Univ., Cairo, 13 (3):717-729.

Ouni, Y.; Ghnaya, T.; Montemurro, F.; Abdelly, C. and Lakhdar, A. (2014). The role of humic substances in mitigating the harmful effects of soil salinity and improve plant productivity. Int. J. Plant Prod., 8, 353-374.

Padda, Kiran Preet; Puri, Akshit; Chanway, Chris P. Meena, Vijay Singh; Mishra, Pankaj Kumar; Bisht, Jaideep Kumar; Pattanayak, Arunava (eds.)and, (2017), "Paenibacillus polymyxa: A Prominent Biofertilizer and Biocontrol Agent for Sustainable Agriculture", Agriculturally Important Microbes for Sustainable Agriculture: Volume 2: Applications in Crop Production and Protection, Springer Singapore, pp. 165-191.

Pandey, A; Namrata, D.; Bhavesh, K.; Rinu, K. and Pankaj, T. (2008). Phosphate solubilization by Penicillium spp. isolated from soil samples of Indian Himalayan region. World J. Microbiol. Biotechnol., 24:97-102.

Pikovskaya, R.I. (1948). Mobilization of phosphorus in soil in connection with vital activity of some microbial species. Mikrobiologiya, 17: 362370 .

Pokhare, S.; Pankaj, T.; Shakil, N.A.; Kumar, J. and Singh, K. (2012). Foliar application of chemical elicitors induces biochemical changes in wheat against the cereal cyst nematode, Heterodera avenae. Nematol. Medit., 40: 181-187.

Radha, T. K.; Savalgi, V. P. and Alagawadi, A. R. (2009). Effect of methylotrophs on growth and yield 
of soybean (Glycine $\max ($ L.) Merrill), Karnataka J. Agric. Sci., 22 (1): 118-121.

Radwan, M.A. and Fatma, M. (2003). Root rot disease of citrus root stocks in relation to citrus nematode. Minufiya J. Agric. Res., 28: 1067-1078.

Renco, M.; Sasanelli, N.; Papajova, I. and Maistrello, L. (2012). Nematicidal effect of chestnut tannin solutions on the potato cyst nematode Globodera rostochiensis (Woll.) Barhens. Helminthologia, 49:108-114.

Rijavec, T. and Lapanje, A. (2016). Hydrogen cyanide in the rhizosphere: not suppressing plant pathogens, but rather regulating availability of phosphate. Frontiers in microbiology, 7, p.1785.

Saraf, M.; Jha, C.K. and Patel, D. (2010). The role of ACC deaminase producing PGPR in sustainable agriculture. In: Maheshwari DK (ed) Plant growth and health promoting bacteria. Springer, Berlin Heidelberg, pp365-385.

Saravanapriya, B. and Subramanian, S. (2007). Management of Meloidogyne incognita on tomato with humic acid and bioinoculants. Ann. Plant Prot. Sci., 15:195-197.

Seenivasan, N. and Senthilnathan, S. (2017). Effect of humic acid on Meloidogyne incognita (Kofoid \& White) Chitwood infecting banana (Musa spp.). Intern. J. Pest management, 64(2): 110-118.

Senthilkumar, M. (2003). Evaluating diazotrophic diversity and endophytic colonization ability Azorhizobium caulinodans and Methylobacterium sp. in bacterised and biotized rice (Oryza sativa L.). Ph.D. Thesis, Tamil Nadu Agric. Univ., Coimbatore (India).

Shehata, Sawsan F.; Abo Taleb, H. H.; Wedad, E. E. Eweda and Heba,O. M. Orf (2006). Growth, Yield and Yield component of Inoculated Chickpea and Faba bean Plants as Affected by Using Methylotrophic Bacteria Arab Univ. J. Agric. Sci. Ain Shams, Univ., Cairo, 14 (2):625-639.

Siddiqui, A.I. and Ehteshamul-Haque, S. (2001). Suppression of the root rot-root knot disease complex by Pseudomonas aeruginosa in tomato: The influence of inoculum density, nematode populations, moisture and other associated plant bacteria. Plant and Soil, 237: 81-89.

Siddiqi, I.A. and Shaukat S.S. (2004). Trichoderma harzianum enhances the production of nematicidal compounds in vitro and improve biocontrol of $M$. javanica by Pseudomonas fluorescens in tomato. Letters in Applied Mycology, 38: 169-175.
Strzelezyk, E.; Gorlack, K. and Rozycki, H. (1990). Chitionlytic and protiolytic activity of streptomycetes isolated from root free soil, rhizosphere and mycorhizosphere of pine (Pinus sylvestrist). Biol. Fertil. Soils, 9: 268-272.

Tchounwou, P.B.; Ashour, B.A.; Young, G.M.; Ragheb, D.A.; Romeh, A.A.; Goma, E.; ElSheikh, S.; Lidell, F.P.; Ibitayo, O. and Assad, J.C. (2002). Health risk assessment of pesticides usage in Menia El-Kamh province of Sharkia governorate in Egypt. Int. J. Mol. Sci., 3 (10): $1082-$ 1094.

Valdrighi, M.M.; Pera, A.; Agnolucci, M.; Frassinetti, S.; Lunardi, D. and Vallini, G. (1996). Effects of compost-derived humic acids on vegetable biomass production and microbial growth within a plant (Cichorium intybus)-soil system: a comparative study. Agriculture, Ecosystems \& Environment, 58: 33-144.

Vallini, A; Pera, L.; Avio, M.; Valdrighi, M. and Giovannetti, M. (1993). Influence of humic acid on laurel growth associatedrhizospheric microorganisms and mycorrhizal fungi. Biol. Fertil. Soils, 16:1-4.

Viswanathan, R.; Rajitha, R.; Sundar, A. R. and Ramamoorthy, V. (2003). Isolation and identification of endophytic bacterial strains from sugarcane stalks and their In Vitro antagonism against the red rot pathogen. Sugarcane, 5: 2529.

Watanabe, F.S. and Olsen, S.R. (1965). Test of an ascorbic acid method for determining phosphorus in water and NaHCO extracts from soil. Soil Sci. Soc. 3 Am. Proc., 29: 677-678.

Xiong, J.; Zhou, Q.; Luo, H.; Xia, L.; Li, L.; Sun, M. and Yu, Z. (2015). Systemic nematicidal activity and biocontrol efficacy of Bacillus firmus against the root-knot nematode Meloidogyne incognita. World J. Microbiol. Biotechnol., 4: 661667.

Zdor, R.E. (2015) Bacterial cyanogenesis: impact on biotic interactions. J. Appl. Microbiol., 118: 267274

Zeinat, K.M.; Nagwa, M.A.; El-Sayed, S.A. and Abd El-Wahab, G.S. (2010). Optimization of microbial biomass production as biocontrol agent against root knot nematode on faba plants. J. Amer. Sci., 6: 245-255.

Zhang, J.; Li, Y.; Yuan, H.; Sun, B. and Li, H. (2016). Biological control of the cereal cyst nematode (Heterodera filipjevi) by Achromobacter xylosoxidans isolate 09X01 and Bacillus cereus isolate 09B18. Biological Control, 92: 1-6. 